\title{
Effect of Preslaughter Bull Handling on Ante Mortem Muscle Glycogen and Post Mortem pH and Glycogen Level (short communication)
}

\begin{abstract}
Summary
Fortythree bulls (13 Holstein, 12 crosses Holstein $x$ Belgium Blue, 9 Slovak Pied and 9 crosses Slovak Pinzgauer $x$ Piemontese) were taken in this experiment. Thirteen were stressed by mixing overnight before slaughter. Muscle values were analysed for glycogen ante mortem (M. semitendinosus), glycogen and $\mathrm{pH}$ post mortem (1h, 3h, 48h) from logissimus dorsi. The ante mortem and post mortem $(1 \mathrm{~h}, 3 \mathrm{~h})$ muscle glycogen concentration was depleted $(\mathrm{P}<0.01)$ in all stressed bulls. Differences $(\mathrm{P}<0.01)$ were found also in pH $(48 \mathrm{~h})$. Significant correlations $(\mathrm{P}<0.01)$ between ante mortem and post mortem $(1 \mathrm{~h}, 3 \mathrm{~h})$ muscle glycogen respectivelly and ultimate $\mathrm{pH}$ supported the possibility to measure of stress and to predict carcass ultimate $\mathrm{pH}$ of bulls.
\end{abstract}

Key words: bulls, stress, muscle, glycogen and $\mathrm{pH}$

\section{Zusammenfassung}

Titel der Arbeit: Einfluß von Streß vor der Schlachtung auf ante mortem Muskelglykogen, post mortem pH und Glykogengehalt bei Bullen (Kurzmitteilung)

Von dreiundfünfzig Mastbullen (13 Holstein, 12 Kreuzung Holstein x Belgium Blau, 9 Slowakisches Fleckvieh und Kreuzung Slowak Pinzgauer x Piemontese) wurden Muskelproben des M. longissimus dorsi von Glykogen ante mortem ( $M$. semitendinosus), Glykogen und $\mathrm{pH}$ post mortem ( $1 \mathrm{~h}, 3 \mathrm{~h}, 48 \mathrm{~h})$ bestimmt.

Der Gehalt an Glykogen ante mortem und post mortem $(1 \mathrm{~h}, 3 \mathrm{~h})$ war in allen gestreßten Bullen vermindert. Unterschiede $(\mathrm{P}<0.01)$ bestanden auch beim pH $(48 \mathrm{~h}$ p.m.). Signifikante Korrelationskoeffizienten zwisçhen Messungen des Glykogengehalts (ante mortem und post mortem) und End-pH post mortem unterstützen die Möglichkeit, die Stressbelastungsfähigkeit und den End-pH-Wert des Fleisches vorherzusagen.

Schlüsselwörter: Bullen, Streß, Muskel, Glykogen, pH-Wert

\section{Introduction}

Domestic animals often experience physiological insults when they are transported and handled. Transport and handling stress could reduce carcass yield, degrade well-being and meat quality. The impact of transport and handling stress on meat quality variables including the rise of low glycogen meat and high pH occurence collectivelly reffered to as dark cutting or dark-firm-dry (DFD) meat (LACOURT and TARRANT, 1985; TARRANT, 1989; ZEMANOVA et al., 1987; MOJTO et al., 1991). Especially mixing of animals is known to contribute to dark cutting (LACOURT and TARRANT, 1985, SANZ et al., 1996). 
Ante mortem stress entails important modifications in post mortem biochemistry of muscle and meat quality. The major effect is exerted through its influence on mobilisation of musle glycogen stores. If these are reduced or depleted before or at slaughter the extent of post mortem acidification is consequently reduced (WARRIS, 1990; SANZ et al., 1996). Ultimate $\mathrm{pH}$ in post mortem bovine muscle may vary between 5.4 and 7.2, showing a direct relationship with stress intensity. The negative effect on meat characteristics of high ultimate $\mathrm{pH}$ caused by stress, due to mixing different male types of cattle, was recently clearly demonstrated (SANZ et al., 1996; BELTRAN et al., 1997).

The aim of this study was to examine the glycogen content ante mortem before slaughter and $\mathrm{pH}$ and glycogen level after slaughter of unstressed and stressed cattle beefs.

\section{Materials and Methods}

\section{Animals, housing and slaughtering}

The animals used in the experiment were 13 Holstein, 12 Holstein $x$ Belgium blue, 9 Slovak bunt and 9 Slovak Pinzgauer x Piemontese bulls, weighing $550 \mathrm{~kg}$. They were fed on supplemented forage diets.

The animals (total 43) were tying housed and divided into the group $A(n=30)$ tying housed and group $B(n=13)$ loose housed (mixed) during night before slaughter. At the abattoir, the animals (group B) were kept overnight and had access to water but not food. Control (group A) and stressed animals (group B) were slaughtered at the Institute abattoir.

\section{Sampling and analytical techniques}

Just before slaughter, biopsy samples (approx. $1 \mathrm{~g}$ ) of semitendinosus muscle (ST) were obtained using efficient non-stress spring loaded biopsy instrument (Biotech, Nitra). Samples of longissimus dorsi musle (LD) were also taken after slaughter (1h, $3 \mathrm{~h}$ and $48 \mathrm{~h}$ ) directly frozen in liquid nitrogen for glycogen analyses (DREILING et al., 1987). $\mathrm{pH}$ was measured in the longissimus muscle (13th rib) using a probe type combined electrode and portable $\mathrm{pH}$ meter (Radelkis, Hungary).

Differences between the means were assessed for statistical significance using an unpaired Student t-test. Correlations between values were also calculated.

\section{Results and Discussion}

As follows from the results (Table 1) of glycogen level ante mortem (just before slaughter) and early post mortem ( $1 \mathrm{~h}$ and $3 \mathrm{~h}$ ) we received significant differences $(\mathrm{P}<0.05)$ of glycogenolysis between the experimental groups.

It was introduced (LACOURT and TARRANT, 1985) adrenalin release causes a general glycogenolytic response throughout the skeletal musculature with glycogen depletion. Mixing of unfamiliar animals can precipitate such events as fighting and mounting and such activities deplete muscle glycogen, especially of the fast twitch 
Table 1

Muscle Glycogen Content $(\mu \mathrm{mol} / \mathrm{g}$ ) and $\mathrm{pH}$ value of unstressed (A) and stressed (B) Bulls (Glykogengehalt des Muskels $(\mu \mathrm{mol} / \mathrm{g})$ und $\mathrm{pH}-$ Wert bei der Kontrollgruppe (A) und den gestreßten (B) Bullen)

\begin{tabular}{lrrrrc}
\hline Values/Animals & \multicolumn{2}{c}{$\mathrm{A}$} & \multicolumn{2}{c}{$\mathrm{B}$} & $\mathrm{p}$ \\
\hline $\begin{array}{l}\text { Ante mortem } \\
\text { glycogen }\end{array}$ & 60.85 & 11.34 & 33.31 & 10.24 & $* *$ \\
$\begin{array}{l}\text { Post mortem } \\
\mathrm{pH}_{1}\end{array}$ & 6.69 & 0.15 & 6.69 & 0.29 & - \\
$\mathrm{pH}_{3}$ & 6.27 & 0.34 & 6.71 & 0.37 & - \\
$\mathrm{pH}_{48}$ & 5.66 & 0.24 & 6.70 & 0.25 & $* *$ \\
glycogen 1h & 55.93 & 12.85 & 22.46 & 8.87 & $* *$ \\
glycogen 3h & 51.88 & 10.03 & 16.78 & 4.84 & $* *$ \\
glycogen 48h & 17.43 & 7.28 & 18.31 & 4.42 & - \\
\hline P & & & & & \\
\hline
\end{tabular}

fibers. In agreement with SANZ et al. (1996) our results supported the idea the main cause of lower glycogen level ante- and early post-mortem and higher ultimate pH (DC condition) was due to physical and emotional stress of mixing unfamiliar bulls at abattoir overnight. Ante-mortem stress entails important modifications in post-mortem biochemistry of muscle. If the muscle glycogen stores are reduced or depleted at slaughter the extent of post mortem acidification is consequently reduced (WARRIS, 1990). Ultimate $\mathrm{pH}$ in post-mortem bovine muscle may vary between 5.4 and 7.2 , showing a direct relationship with stress intensity (BELTRAN et al., 1997). As follows from our results (Table 2) we received significant $(\mathrm{P}<0.01)$ correlation between glycogen level ante- and early post-mortem $(1 \mathrm{~h}, 3 \mathrm{~h})$ and ultimate $\mathrm{pH}\left(\mathrm{pH}_{48}\right)$. Correlations with three-hour post-mortem muscle $\mathrm{pH}\left(\mathrm{pH}_{3}\right)$ were not significant $(\mathrm{P}>0.05)$. The results are in agreement with SHACKELFORD et al. (1994), they showed also lower correlations of $\mathrm{pH}_{3}$ with $\mathrm{pH}_{\mathrm{u}}$ and tenderness and $\mathrm{pH}_{3}$ was not enough effective in grouping stressed and unstressed animals in our experiment.

Table 2

Correlations between glycogen level and $\mathrm{pH}$ values of control and experimental bulls $(\mathrm{A}+\mathrm{B} ; \mathrm{n}=43)$ (Korrelationkoeffizienten zwischen Glykogengehalt und pH-Wert aller Bullen)

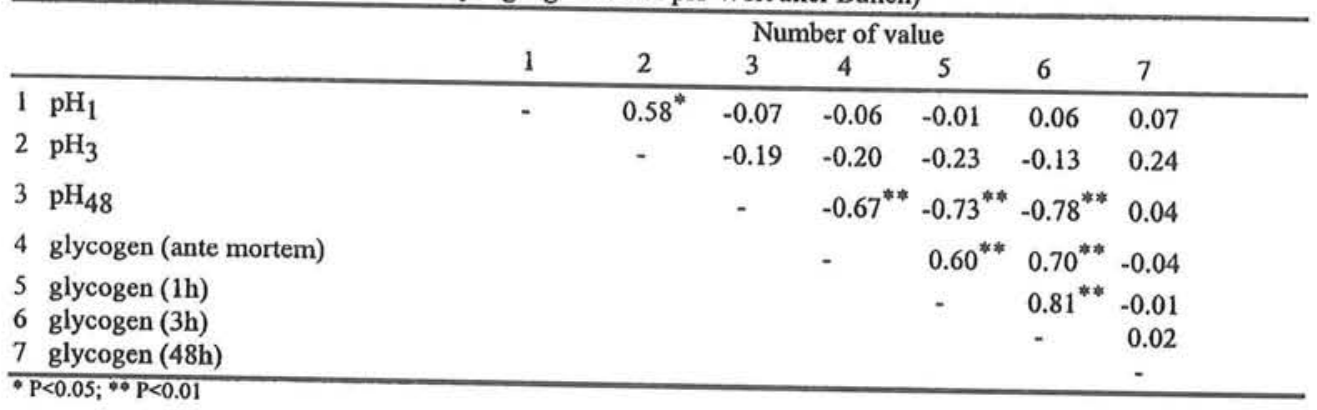

In conclusion, the glycogen level ante-mortem (just before slaughter) and early postmortem $(1 \mathrm{~h}, 3 \mathrm{~h})$ was good predictor for assessing handling stressors and carcass ultimate $\mathrm{pH}\left(\mathrm{pH}_{48}\right)$ of bulls. 


\section{References}

BELTRÁN, J.A.; JAIME, I.; SANTOLARIA, P.; SANUDO, C.; ALBERTI, P.; RONCALÉS, P.:

Effect of Stress-induced High Post-mortem pH on Protease Activity and Tenderness of Beef. Meat Sci. 4 (1997) 2, 201-207

DREILING, C.E.; BROWN, D.E.; CASALE, L.; KELLY, L.:

Muscle glycogen: Comparison of Jodine Binding and Enzyme Digestion Assays and Application to Meat Samples. Meat Sci. 20 (1987), 167-177

LACOURT, A.; TARRANT, P.:

Epuissement du glycogéne dans le muscle bovin pendant le stress. Meat Sci., 15 (1985) 2, 85-100

MOJTO, J.; SZAKACSOVA, D.; KMETOVA, E.:

Content of muscle glycogen and meat quality of bulls and cows. (Czech Language). Polnohospodarstvo (Agriculture, Nitra, Slovakia), 37 (1991) 9-10, 801-806

TARRANT, P.V.: Animal behaviour and environment in the dark cutting condition in beef. Ir. J. Food Sci. Technol., 13 (1989), 1-14

SANZ, M.C.; VERDE, M.T.; SÁEZ, T.; SANUDO, C.:

Effect of Breed on the Muscle Glycogen Content and Dark Cutting Incidence in Stressed Young Bulls. Meat Sci. 43 (1996) 1, 37-42

SHACKELFORD, S.D.; KOOHMARAIE, M.; SAVELL, J.W.: Evaluation of Longissimus dorsi Muscle $\mathrm{pH}$ at Tree Hours Post Mortem as a Predictor of Beef Tenderness. Meat Sci. 37 (1994), 195-204

WARRIS, P.D.:

The handling of cattle pre-slaughter and its effects on carcass and meat quality. Appl. Anim. Behav. Sci., 28 (1990), 171-178

ZEMANOVA, D.; KOMENDA, V.; NOVOTNA, B.; DVOAAK, Z.: Occurence of DFD meat quality and its detection just after slaughter. (Czech Language). Vet. Med. (Prague), 32 (1987) 9, 525-534

Received: 08.04.1998

Accepted: 19.02 .1999

Author $s$ addresses

Dr. RUDOLF LAHUCKY, OLGA PALANSKA, JOZEF MOJTO,

KVETOSLAV ZAUJEC, Ing. JAN HUBA, Csc.

Research Institute of Animal Production

Hlohovska 2

94992 Nitra

Slovakia 